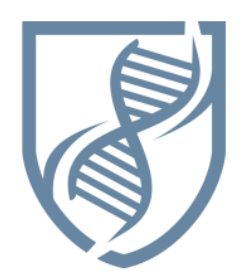

\title{
Clinical Manifestations of Philadelphia-negative Myeloproliferative Neoplasms in Sudan
}

\section{Sahar Elbager 1, Enaam Abdelgader ${ }^{2}$, Samah Ali 1, Tahani Mursal 1, Nahid Yousif ${ }^{\text {, }}$, Eltaher Osman $^{3}$, Amar Dowd 1, Magdi Bayoumi 1,3}

Faculty of Medical Laboratory Sciences, University of Medical Sciences and Technology (UMST), Sudan ${ }^{1}$. Radiation and Isotope Center - Khartoum (RICK), Sudan ${ }^{2}$

Sudan Medical and \& Scientific Research Institute (SUMASRI) University of Medical Sciences and Technology (UMST), Sudan ${ }^{3}$

(Email: corresponding saharelbager@gmail.coms )

Received: February 25, 2018. Accepted: May 25, 2018. Published: June 1, 2018

DOI: $10.21608 /$ JBAAR.2018.129897

\begin{abstract}
Background/ objective: The Philadelphia-negative chronic myeloproliferative neoplasms (MPNs), is a heterogeneous group of oncohematological diseases that express a high burden of symptoms that significantly affect patient quality of life and are associated with high morbidity and premature mortality. This study aimed to determine the clinical manifestations of MPNs in the Sudanese population. Method: A retrospective study was carried out in the Radiation and Isotope Center at Khartoum (RICK), Sudan. 290 medical records of MPNs were examined. Results: Polycythemia Vera (PV) was the most frequent $(64.1 \%)$ with a median age at diagnosis of 50 years. It was, followed by Essential Thrombocythemia (ET) (28.6\%, median age 48years) and Primary Myelofibrosis (PMF) (7.3\%, median age 58years). Male patients had mostly a history of PV $(\mathrm{p}<0.05)$. Females were predominately affected by ET $(\mathrm{p}<0.05)$, despite the gender distribution of PMF patients was approximately similar ( $\mathrm{p}>0.05$ ). Among PV cases, the main symptoms present at diagnosis were fatigue with fever reported by $31.2 \%$ of cases followed by headache (26.6\%), joint pain (24.2\%), splenomegaly (14.2\%), hepatosplenomegaly, and thrombotic complications. In ET, $43.4 \%$ of the cases complained about headache followed by fatigue associated with fever, joint pain, splenomegaly, hepatosplenomegaly. None of the ET cases presented bleeding or thrombotic complications. In PMF cases, the main symptoms were fatigue with fever (19\%) followed by joint pain, headache, fever, bleeding, thrombotic complication, splenomegaly, hepatosplenomegaly.

Conclusion: The current study showed that in Sudan, MPNs affect a younger population and PV was more prevalent than ET and PMF. The findings also revealed that headache, fatigue, and joint pain were the most frequent symptoms.
\end{abstract}

Keywords: Clinical Manifestations, Essential Thrombocythemia, Polycythemia Vera, Primary Myelofibrosis, Sudan.

\section{Introduction}

Myeloproliferative disorders (MPDs) were firstly described by an American hematologist, Dr. William Dameshek, in 1951 (Dameshek, 1951). They are a heterogeneous group of oncohematological diseases characterized by excess hematopoiesis affecting one or more myeloid cell lineages leading to an overproduction of both mature and immature cells. The four initial subtypes of MPDs, include chronic myeloid leukemia (CML), polycythemia vera (PV), essential 
thrombocythemia (ET), and primary myelofibrosis (PMF), this classification based on clinical findings including the peripheral blood and bone marrow smear (Dameshek, 1951). This classification was subsequently revised, in 2001, the World Health Organization (WHO) adding laboratory findings and evaluation of the bone marrow as diagnostic criteria of these disorders(Vardiman JW, 2003). In the 2008 World Health Organization classification system of myeloid neoplasms system replaced the term (MPDs) with myeloproliferative neoplasms (MPNs). Also, the diagnostic criteria for PV, ET, and PMF were revised by incorporating new information on their clinical characteristic, cytogenetics changes, and molecular pathogenesis(Tefferi A, 2008). The 2016 revision of the World Health Organization classification of myeloid neoplasms(Arber DA, 2016), a consensus among hematopathologists, hematologists, geneticists, and clinicians, revised the prior classification rather than an entirely new classification, refines the diagnostic criteria for some entities, details the expanding genetic/molecular landscape (e.g. JAK2, CALR, and MPL mutations) and their clinical correlates, and refers to investigations leading to more targeted therapeutic strategies.

PV is characterized by the overproduction of mature red blood cells in the bone marrow leading to an increased red blood cell mass and increased blood viscosity predisposing patients to thrombosis. ET is characterized by proliferation of megakaryocytes in the bone marrow resulting in marked thrombocytosis, which increases the risk of thrombosis and hemorrhagic events; while the PMF is characterized by the hematopoietic stem cell expansion in the bone marrow accompanied by a reactive nonclonal fibroblastic proliferation, marrow fibrosis, and extramedullary hematopoiesis often resulting in hepatosplenomegaly (Campbell PJ, 2006).

Gender appears to influence MPNs subtype. The prevalence of PV is slightly higher in male (maleto-female ratio, 1.8:1), ET is more prevalent in female (male-to-female ratio, 1:2 ) and the overall incidence of PMF is approximately the same in male and female (Passamonti F, 2004, Geyer HL, 2017, Stein BL, 2011). Although the pathogeny of this discordance remains unclear, some recent studies suggest that sex chromosome complement, an influence of sex hormones, immune-competence, and gene expression may all be possible contributors to this discordance in disease burden (Ober C, 2008, Ellegren H, 2007).

Most patients are diagnosed with MPNs after age
60; however, the diseases can occur at any age. The median age at diagnosis of PV is approximately 64 years; 55 years for ET and 65 years for $\mathrm{MF}$ (Srour SA, 2016, Tefferi A, 2012).

Patients with MPNs experience a high burden of symptoms that significantly affect their quality of life and lead to significant morbidity and premature mortality. The profiles of symptoms of these MPNs are heterogeneous even among patients within the same MPN subtypes. Symptoms include excessive sweating, fatigue, bruising, headaches, concentration problems, bleeding and abdominal discomfort, and/or pain (Mesa RA, 2007, Michiels, 2015b, Mesa R, 2016). Although considered relatively indolent diseases, MPNs are at lifelong enhanced risk of thrombosis, hemorrhage, and myelofibrotic or leukemic transformation which contributes to extensive morbidity and mortality (Mughal et al., 2014, Spivak et al., 2003). This study aimed to determine the clinical manifestations of MPNs in the Sudanese population.

\section{Materials and Methods}

\subsection{Data collection}

A retrospective cross-sectional study was carried out in the Radiation and Isotope Center at Khartoum (RICK), Sudan. (RICK) is located in the capital city (Khartoum). It is a tertiary level center with facilities to diagnose and treat the disease using radioactive isotopes. RICK is located in the capital city (Khartoum). The center is the countrywide referral facility; diagnose and treat the disease using radioactive isotopes

For data collection, a standardized research tool was used to collect information on characteristics of patients, disease symptoms, laboratory data at diagnosis, and complications.

Given that there is no proper and effective hospital record-keeping system in Sudan, we were faced with the problem of missing data; the study cases were selected based on the recorded distinct diagnosis of MPNs, availability of clinical features, and laboratory information at the time of initial diagnosis. Record with incomplete demographic features and patient characteristics, laboratory diagnosis, or distinctive subtype MPNs, were excluded.

Diagnoses were approved based on clinical features, blood counts, peripheral blood films, and bone marrow morphology. As we had limited facilities for molecular studies, some cases were diagnoses based on WHO classification whenever facilities were available. In the end, 290 diagnosed cases were reviewed after excluding $86(22.9 \%$, 86/376).

\subsection{Statistical analysis}

Data collected were analyzed through Excel 2007 
and a statistical package for social sciences (SPSS version 20). The variables were first assessed by Kolmogorov Smirnov/Shapiro-Wilk testing in terms of normal distribution. The results were provided as median (minimum-maximum) for abnormally distributed parameters. Statistical significance was set at $\mathrm{p}<0.05$.

Demographic and disease characteristics of the patients were summarized graphically in form of frequency tables and the continuous variables expressed as median

\subsection{Ethical considerations}

The study was approved by the national health research ethics committee of the Sudan Ministry of Health. In this retrospective study, obtaining informed consent was not possible.

\section{Results}

\subsection{Demographic characteristics of patients}

All medical records of 290 MPNs cases were prospectively evaluated (male; $\mathrm{n}=180,62.1 \%$ / female; $n=110,37.9 \%$ ), with a male to female ratio of 1.6:1.

PV was the most frequent MPN (64.1\%) followed by ET $(28.6 \%)$ and MF $(7.3 \%)$ as revealed by table 1

\subsubsection{Polycythemia Vera}

The mean age at diagnosis of PV was 50 years (range: 17-85 years), most male patients having a history of PV (77.2 \% males versus $42.7 \%$ females, $p=0.000$ ), table 1 .

The age distribution revealed (Table 2) that PV affected mostly young adults aged 20-49 years (52.2\%). $82.3 \%$ of PV cases were symptomatic (Table 3). The main symptoms present at diagnosis (figures 1 and 2) were fatigue plus fever reported by $31.2 \%$ of cases, headache $(29.6 \%)$, joint pain (24.2\%), splenomegaly (14.0. \%), hepatosplenomegaly (3.8\%), and thrombotic complications $(1.1 \%)$.

\subsubsection{Essential Thrombocythemia}

As shown in table 1, the mean age at diagnosis of ET was 48 years (range: $25-80$ years), females were predominant $(50.0 \%$ versus $15.5 \%, p=0.000)$. The age distribution (table2) showed that ET mostly occurred among young adults aged 20-49 years $(61.4 \%)$.

Table 3 revealed that $81.9 \%$ of ET cases were symptomatic. $43.4 \%$ of cases presented with headache, fatigue with fever $(31.3 \%)$ joint pain $(31.3 \%)$, splenomegaly $(21.7 \%)$, hepatosplenomegaly (2.4\%), none of ET cases presented bleeding or thrombotic complications (figures 1 and 2).

\subsubsection{Primary Myelofibrosis}

In our study, the median age at diagnosis was 58 years (range, 33-80 years). The gender distribution was approximately similar $(7.2 \%$ versus $7.3 \%, p>$ $0.05)$. The most affected group was older patients aged 60 years and above (tables $1 \& 2$ ). $71.4 \%$ $(15 / 21)$ of MF cases were symptomatic (tables 3$)$. Joint pain and fatigue with fever were the most frequent symptoms (figure 1).

Figure 2 revealed that splenomegaly was the predominant complication followed by hepatosplenomegaly. Thrombotic and bleeding complications had the same frequency.

Table 1: Demographics distribution pattern of MPNs Patients

\begin{tabular}{cccc}
\hline Characteristics & PV & ET & MF \\
\hline Cases no.(\%) & 186 & 83 & 21 \\
& $(64.1 \%)$ & $(28.6 \%)$ & $(7.3 \%)$ \\
Median age in & 50 & 48 & 58 \\
years (range) & $(17-85)$ & $(25-80)$ & $(33-80)$ \\
Gender & & & \\
Male n (\%) & 139 & 28 & 13 \\
& $(77.2 \%)$ & $(15.5 \%)$ & $(7.2 \%)$ \\
Female n (\%) & 47 & 55 & 8 \\
& $(42.7 \%)$ & $(50.0 \%)$ & $(7.3 \%)$ \\
p-value & 0.000 & 0.000 & 0.725 \\
\hline
\end{tabular}

Table 2: Age-group distribution of MPNs

\begin{tabular}{cccc}
\hline $\begin{array}{c}\text { Age group } \\
\text { (years) }\end{array}$ & $\begin{array}{c}\text { PV } \\
\text { no. }(\%)\end{array}$ & $\begin{array}{c}\text { ET } \\
\text { no. }(\%)\end{array}$ & $\begin{array}{c}\text { MF } \\
\text { no. }(\%)\end{array}$ \\
\hline$<20$ & $2(1.1 \%)$ & $0(0.0 \%)$ & $0(0 \%)$ \\
$20-29$ & $28(15.1 \%)$ & $10(12.0 \%)$ & $0(0 \%)$ \\
$30-39$ & $26(14.0 \%)$ & $16(19.3 \%)$ & $3(14.3 \%)$ \\
$40-49$ & $43(23.1 \%)$ & $25(30.1 \%)$ & $2(9.5 \%)$ \\
$50-59$ & $40(21.5 \%)$ & $18(21.7 \%)$ & $3(14.3 \%)$ \\
$60-69$ & $27(14.5 \%)$ & $6(7.2 \%)$ & $11(52.4 \%)$ \\
$70+$ & $20(10.7 \%)$ & $8(9.7 \%)$ & $2(9.5 \%)$ \\
\hline
\end{tabular}

Table 3: Circumstance of disease detection Characteristics of the patients

\begin{tabular}{cccc}
\hline $\begin{array}{c}\text { Circumstance } \\
\text { of detection }\end{array}$ & $\begin{array}{c}\text { PV } \\
\text { no.(\%) }\end{array}$ & $\begin{array}{c}\text { ET } \\
\text { no.(\%) }\end{array}$ & $\begin{array}{c}\text { MF no. } \\
(\%)\end{array}$ \\
\hline Incidental & 32 & 15 & 6 \\
& $(17.2 \%)$ & $(18.1 \%)$ & $(28.6 \%)$
\end{tabular}

$\begin{array}{llll}\text { Symptomatic } & 154 & 68 & 15\end{array}$ $(82.3 \%) \quad(81.9 \%) \quad(71.4 \%)$ 


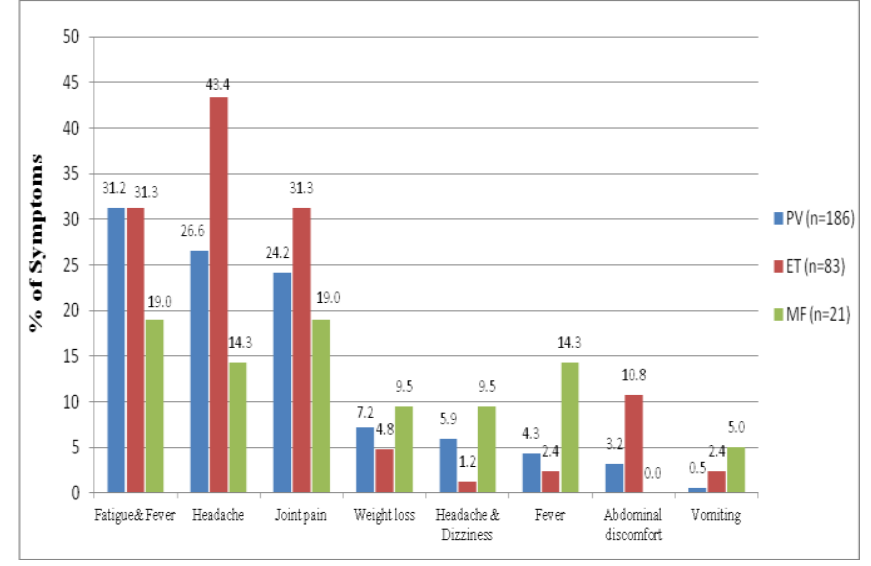

Figure 1: Symptoms by MPN subtypes

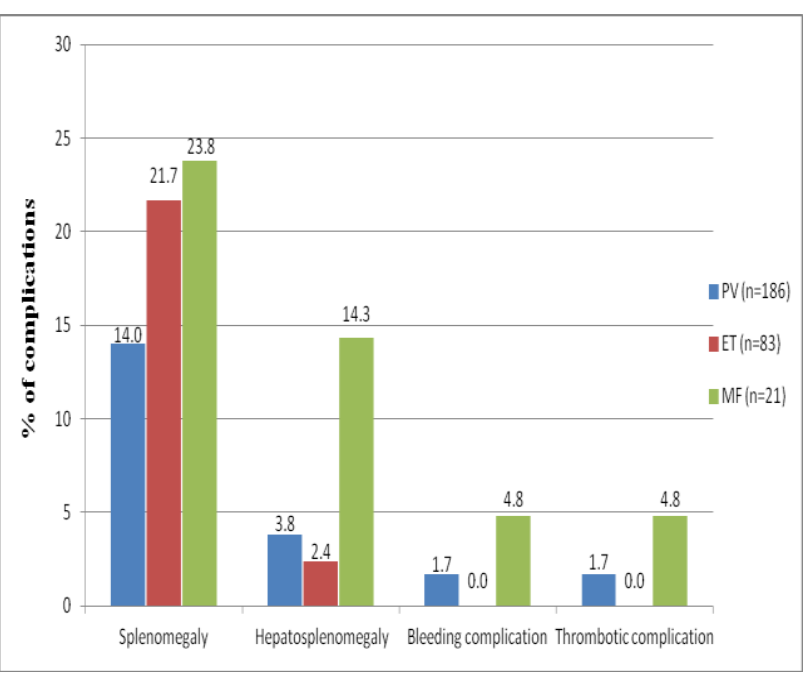

Figure 2: Complications by MPN subtypes

\section{Discussion}

Understanding the clinical manifestations of MPNs is crucial to guide physicians to apply a therapeutic strategy for managing MPNs patients -reducing the risk of complications and improving quality of lifeprovide information to assess the value of new drugs, changes, or revision of criteria for treatment response.

In 2013, the European LeukemiaNet (ELN) Consortium and International Working GroupMyeloproliferative Neoplasms Research and Treatment (IWG-MRT), revised the treatment response criteria for PV, ET, and PMF. Some of the changes in treatment response criteria include consideration of the Myeloproliferative Neoplasm Symptom Assessment Form as a tool for assessing therapeutic outcomes in patients with ET and PV being treated with novel therapeutic agents (Barosi G, 2013, Tefferi A, 2013).
Our study on myeloproliferative neoplasms revealed that PV (63.0\%) was the most frequent MPN in Sudan followed by ET and PMF.

\subsection{Polycythemia vera}

In our study, the median age at diagnosis of PV was 50 years, a similar median age was reported by Yesilova AM at al (53 years) (Yesilova AM, 2017). However, a higher median age (60-71 years) was reported elsewhere in the literature (Passamonti et al., 2004, Bonicelli et al., 2013, Srour et al., 2016). Males were more likely to have PV as pointed out by, previous studies (Geyer et al., 2017, Stein et al., 2013, Mehta et al., 2014). Our findings indicated that $53.2 \%$ of the PV $(n=186)$ affected young adults aged 20-49 years. Although PV had been reported in elders with a median age at diagnosis of 60 years, approximately 20 to $25 \%$ of PV patients were younger than 40 years (Tibes and Mesa, 2013). Stein BL et al. (Stein et al., 2013) reported that younger patients diagnosis with PV were at a significantly higher risk for complications, including splenic vein thrombosis. As in older patients, their disease tended towards, myelofibrosis and/or leukemia. Consequently, physicians should be alert to younger patients suffering from PV and should apply a treatment protocol for delaying or reducing the risk of complications.

Fatigue and headache are the most common neurological symptoms reported affecting MPNs patients, limiting their involvement in social and physical activities (Scherber et al., 2011, Hensley et al., 2013, Mesa et al., 2007, Michiels, 2015a, Mesa et al., 2016). In our research, the main symptoms present at diagnosis of PV were fatigue with fever and headache. Recent studies have demonstrated that fatigue has been closely associated with depressed mood in MPNs (Tibes R, 2013). The combination of cancer-related depression and fatigue also contribute to affect the quality of life. Thrombotic complications are the leading cause of mortality in MPNs. In general, the incidence of thrombosis at the time of diagnosis ranges between $12.0 \%$ and $40 \%$ for PV (Tibes R, 2013, Hensley B, 2013). A thrombotic complication was $1.1 \%$ in our study. Our cases with thrombotic complications were mostly $<60$ years and without a previous history of thrombosis or cardiovascular risk.

\subsection{Essential Thrombocythemia}

In our research female patients were more likely to have ET $(50.0 \%)$, this is tallied with published data (Passamonti F, 2004, Stein BL, 2011, Srour SA, 2016). The median age of ET patients at diagnosis was 48 years, a higher median age (66-68 years) at presentation years was reported in other studies (Oliva EN, 2012, Cortelazzo S, 1995). Although ET 
was reported in the older adult, limited published data is available on young adult groups with a median around 35 years (Finazzi G, 2003, AlvarezLarran A, 2007). This is consistent with our results revealing that ET mostly occurred among young adults aged 20-49 years. Barbui et al. (Barbui T, 2012) hypothesized that young adults with ET may be characterized by different biology and a higher rate of events due to longer disease duration. They suggested caution in prescribing aspirin and drugs such as anagrelide, which are reported to be associated with an increased risk of myelofibrosis development.

Neurological symptoms including headache and dizziness are frequently encountered as clinical manifestations in ET (Michiels, 2015b). In our study headache was the most frequent symptom in ET. Few studies investigating the frequency of headaches as complain when diagnosing patients with ET. One study reported that $13.5 \%$ of ET patients complained of a headache at diagnosis (Billot S, 2011)[30]. Barbie et al (Barbui T, 2011) reported that ET-related headaches can be attributed to hypertension. Hypertension is one of the cardiovascular risk factors. Therefore, physicians must be able to differentiate headache as a primary problem, or a consequence of ET.

Thrombotic complications in ET at the time of diagnosis ranges between $7.0 \%$ and $26.0 \%$ (Barbui T, 2012) In our study none of the ET cases presented thrombotic complications. Similar to PV, most of the ET cases were at low risk of thrombotic complications.

Splenomegaly is a commonly abdominal-related complaint of 5-20\% in ET patients at diagnosis (Barbui et al., 2012, Passamonti and Rumi, 2009, Campbell et al., 2005, Andriani et al., 2016). Consistent with the literature, baseline splenomegaly was present in $21.7 \%$ of the ET cases in our study. A recent retrospective study indicated that baseline splenomegaly seems to be an independent additional risk factor for thrombosis in ET patients (Andriani et al., 2016).

\subsection{Primary Myelofibrosis}

Our findings revealed that males and females were approximately affected, consistent with published data (Tefferi A, 2012). The median age at diagnosis of PMF was 58 years, a similar median age was reported by Mesa and colleagues (58 years) (Mesa R, 2016). However, the higher median age was reported in other studies, where the reported median age was between 65 and 70 years (Tefferi et al., 2012, Cervantes et al., 2009, Mitra et al., 2013, Srour et al., 2016)
Less attention was paid to the frequency of thrombotic complications, but it was reported to be similar to that observed in ET (Barbui T, 2010). Thrombotic complications were not frequent (5\%) in our research, which may be due to the small number of PMF cases.

Few published studies have described the symptomatic burden among PMF patients; fever, fatigue, and joint pain were the most frequent symptoms reported (Michiels, 2015b, Hensley B, 2013) [13, 24]. In our study, fever, fatigue, and joint pain were reported with less frequency.

Splenomegaly is a common sign present in $10-56 \%$ of PMF patients at diagnosis. It contributes to the morbidity in PMF (Mesa et al., 2007, Mitra et al., 2013, Barosi, 2011, Mesa et al., 2006)]. In our study, splenomegaly occurred in $23.8 \%$.

In Conclusion, the current study showed that in Sudan, MPNs affect a younger population and PV was more prevalent than ET and PMF. The findings also revealed that headache, fatigue, and joint pain were the most frequent symptoms in all MPNs subtypes. Further investigations are necessary to understand the biology and genetics of MPNs in Sudan.

\section{References}

ALVAREZ-LARRAN A, C. F., BELLOSILLO B, GIRALT M, JULIA A, HERNANDEZBOLUDA JC, ET AL 2007. Essential thrombocythemia in young individuals: frequency and risk factors for vascular events and evolution to myelofibrosis in 126 patients. Leukemia. 2007;21(6):1218-23.

ANDRIANI, A., LATAGLIATA, R., ANACLERICO, B., SPADEA, A., RAGO, A., DI VEROLI, A., SPIRITO, F., PORRINI, R., DE MURO, M., CRESCENZI LEONETTI, S., VILLIVA, N., DE GREGORIS, C., MONTEFUSCO, E., POLVERELLI, N., SANTORO, C., BRECCIA, M., CIMINO, G., MAJOLINO, I., MAZZUCCONI, M. G., VIANELLI, N., ALIMENA, G., MONTANARO, M. \& PALANDRI, F. 2016. Spleen enlargement is a risk factor for thrombosis in essential thrombocythemia: Evaluation on 1,297 patients. Am J Hematol, 91, 318-21.

ARBER DA, O. A., HASSERJIAN R, ET AL. 2016. The 2016 revision to the World Health Organization classification of myeloid neoplasms and acute leukemia. . Blood. , 127, 2391-2405.

BARBUI T, B. G., BIRGEGARD G, CERVANTES F, FINAZZI G, GRIESSHAMMER M, ET AL. 2011. Philadelphia-negative classical myeloproliferative neoplasms: critical concepts and management recommendations from European LeukemiaNet. Journal of clinical oncology: official journal of the American 
Society of Clinical Oncology. 2011;29(6):761-

70. Philadelphia-negative classical myeloproliferative neoplasms: critical concepts and management recommendations from European LeukemiaNet. Journal of clinical oncology: official journal of the American Society of Clinical Oncology. 2011;29(6):76170. .

BARBUI, T., FINAZZI, G., CAROBBIO, A., THIELE, J., PASSAMONTI, F., RUMI, E., RUGGERI, M., RODEGHIERO, F., RANDI, M. L., BERTOZZI, I., GISSLINGER, H., BUXHOFER-AUSCH, V., DE STEFANO, V., BETTI, S., RAMBALDI, A., VANNUCCHI, A. M. \& TEFFERI, A. 2012. Development and validation of an International Prognostic Score of thrombosis in World Health Organizationessential thrombocythemia (IPSET-thrombosis). Blood, 120, 5128-33; quiz 5252.

BARBUI T, T. J., CAROBBIO A, PASSAMONTI F, RUMI E, RANDI ML, ET AL. 2012. Disease characteristics and clinical outcome in young adults with essential thrombocythemia versus early/prefibrotic primary myelofibrosis. Blood. 2012;120(3):569-71.

BAROSI, G. 2011. Conventional and Investigational Therapy for Primary Myelofibrosis. In: VERSTOVSEK, S. \& TEFFERI, A. (eds.) Myeloproliferative Neoplasms: Biology and Therapy. Totowa, NJ: Humana Press.

BAROSI G, M. R., FINAZZI G, HARRISON C, KILADJIAN JJ, LENGFELDER E, ET AL. 2013. Revised response criteria for polycythemia vera and essential thrombocythemia: an ELN and IWG-MRT consensus project. . Blood. 2013;121(23):477881.

BILLOT S, K. E., LE GUILLOUX J, CASSINAT B, JARDIN C, LAPERCHE T, ET AL. 2011. Neurological disorders in essential thrombocythemia. Haematologica. 2011;96(12):1866-9.

BONICELLI, G., ABDULKARIM, K., MOUNIER, M., JOHANSSON, P., ROSSI, C., JOOSTE, V., ANDREASSON, B., MAYNADIE, M. \& GIRODON, F. 2013. Leucocytosis and thrombosis at diagnosis are associated with poor survival in polycythaemia vera: a populationbased study of 327 patients. Br J Haematol, 160, 251-4.

CAMPBELL PJ, G. A. 2006. The Myeloproliferative Disorders. . New England Journal of Medicine. 2006;355(23):2452-66. .

CAMPBELL, P. J., SCOTT, L. M., BUCK, G., WHEATLEY, K., EAST, C. L., MARSDEN, J. T., DUFFY, A., BOYD, E. M., BENCH, A. J., SCOTT, M. A., VASSILIOU, G. S., MILLIGAN, D. W., SMITH, S. R., ERBER, W. N., BAREFORD, D., WILKINS, B. S., REILLY, J. T., HARRISON, C. N. \& GREEN, A. R. 2005. Definition of subtypes of essential thrombocythaemia and relation to polycythemia vera based on JAK2 V617F mutation status: a prospective study. Lancet, 366, 1945-53.

CERVANTES, F., DUPRIEZ, B., PEREIRA, A., PASSAMONTI, F., REILLY, J. T., MORRA, E., VANNUCCHI, A. M., MESA, R. A., DEMORY, J. L., BAROSI, G., RUMI, E. \& TEFFERI, A. 2009. New prognostic scoring system for primary myelofibrosis based on a study of the International Working Group for Myelofibrosis Research and Treatment. Blood, 113, 2895-901.

CORTELAZZO S, F. G., RUGGERI M, VESTRI O, GALLI M, RODEGHIERO F, ET AL. 1995. Hydroxyurea for patients with essential thrombocythemia and a high risk of thrombosis. The New England journal of medicine. 1995;332(17):1132-6.

DAMESHEK, W. 1951. Some speculations on the myeloproliferative syndromes. Blood. , 6, 3725 . .

ELLEGREN H, P. J. 2007. The evolution of sex-biased genes and sex-biased gene expression. Nature Reviews Genetics. 2007;8(9):689-98.

. Nature reviews Genetics. 2007;8(9):689-98.

FINAZZI G, R. M., RODEGHIERO F, BARBUI T. 2003. Efficacy and safety of long-term use of hydroxyurea in young patients with essential thrombocythemia and a high risk of thrombosis. Blood. 2003;101(9):3749-.

GEYER HL, K. H., DUECK AC, SCHERBER R, SLOT S, ZWEEGMAN S, ET AL. 2017. Associations between gender, disease features and symptom burden in patients with myeloproliferative neoplasms: an analysis by the MPN QOL International Working Group. Haematologica. , 102, 85-93

GEYER, H. L., KOSIOREK, H., DUECK, A. C., SCHERBER, R., SLOT, S., ZWEEGMAN, S., TE BOEKHORST, P. A. W., SENYAK, Z., SCHOUTEN, H. C., SACKMANN, F., FUENTES, A. K., HERNÁNDEZ-MARAVER, D., PAHL, H. L., GRIESSHAMMER, M., STEGELMANN, F., DÖHNER, K., LEHMANN, T., BONATZ, K., REITER, A., BOYER, F., ETIENNE, G., IANOTTO, J. C., RANTA, D., ROY, L., CAHN, J. Y., HARRISON, C. N., RADIA, D., MUXI, P., MALDONADO, N., BESSES, C., CERVANTES, F., JOHANSSON, P. L., BARBUI, T., BAROSI, G., VANNUCCHI, A. M., PAOLI, C., PASSAMONTI, F., ANDREASSON, B., FERRARI, M. L., RAMBALDI, A., SAMUELSSON, J., CANNON, K., BIRGEGARD, G., XIAO, Z., XU, Z., ZHANG, Y., SUN, X., XU, J., KILADJIAN, J. J., ZHANG, P., GALE, R. P. \& MESA, R. A. 2017. Associations between gender, disease features and symptom burden in patients with myeloproliferative neoplasms: an 
analysis by the MPN QOL International Working Group. Haematologica, 102, 85-93.

HENSLEY, B., GEYER, H. \& MESA, R. 2013. Polycythemia vera: current pharmacotherapy and future directions. Expert Opin Pharmacother, 14, 609-17.

HENSLEY B, G. H., MESA R. 2013. Polycythemia vera: current pharmacotherapy and future directions. Expert opinion on pharmacotherapy. 2013;14(5):609-17.

MEHTA, J., WANG, H., IQBAL, S. U. \& MESA, R. 2014. Epidemiology of myeloproliferative neoplasms in the United States. Leuk Lymphoma, 55, 595-600.

MESA R, M. C., THYNE M, MANGAN J, GOLDBERGER S, FAZAL S, ET AL. 2016. Myeloproliferative neoplasms (MPNs) have a significant impact on patients' overall health and productivity: the MPN Landmark survey. BMC Cancer. 2016;16:167.

MESA, R., MILLER, C. B., THYNE, M., MANGAN, J., GOLDBERGER, S., FAZAL, S., MA, X., WILSON, W., PARANAGAMA, D. C., DUBINSKI, D. G., BOYLE, J. \& MASCARENHAS, J. O. 2016. Myeloproliferative neoplasms (MPNs) have a significant impact on patients' overall health and productivity: the MPN Landmark survey. BMC Cancer, 16, 167.

MESA, R. A., NAGORNEY, D. S., SCHWAGER, S., ALLRED, J. \& TEFFERI, A. 2006. Palliative goals, patient selection, and perioperative platelet management: outcomes and lessons from 3 decades of splenectomy for myelofibrosis with myeloid metaplasia at the Mayo Clinic. Cancer, 107, 361-70.

MESA, R. A., NIBLACK, J., WADLEIGH, M., VERSTOVSEK, S., CAMORIANO, J., BARNES, S., TAN, A. D., ATHERTON, P. J., SLOAN, J. A. \& TEFFERI, A. 2007. The burden of fatigue and quality of life in myeloproliferative disorders (MPDs): an international Internet-based survey of 1179 MPD patients. Cancer, 109, 68-76.

MESA RA, N. J., WADLEIGH M, VERSTOVSEK S, CAMORIANO J, BARNES S, ET AL. 2007. The burden of fatigue and quality of life in myeloproliferative disorders (MPDs). Cancer. 2007;109(1):68-76.

MICHIELS, J. 2015. Signs and Symptoms of Myeloproliferative Neoplasms (MPN), Quality of Life, Social Activity, Work Participation and the Impact of Fatigue in Dutch MPN Patients: A One Country Questionnaire Investigation of 497 MPN Patients.

MITRA, D., KAYE, J. A., PIECORO, L. T., BROWN, J., REITH, K., MUGHAL, T. I. \& SARLIS, N. J. 2013. Symptom burden and splenomegaly in patients with myelofibrosis in the United States: a retrospective medical record review. Cancer Medicine, 2, 889-898.

MUGHAL, T. I., VADDI, K., SARLIS, N. J. \& VERSTOVSEK, S. 2014. Myelofibrosisassociated complications: pathogenesis, clinical manifestations, and effects on outcomes. International Journal of General Medicine, 7, 89-101.

OBER C, L. D., GILAD Y. 2008. Sex-specific genetic architecture of human disease. . Nature reviews Genetics. , 9(12):911-22.

OLIVA EN, P. A., MAZZUCCONI MG, MORRA E, RECINE U, POGLIANI EM, ET AL. 2012. Quality of life in elderly patients with essential thrombocythaemia. An Italian multicentre study. Annals of hematology. 2012;91(4):52732. .

PASSAMONTI F, R. E., PUNGOLINO E, MALABARBA L, BERTAZZONI P, VALENTINI M, ET AL. 2004. Life expectancy and prognostic factors for survival in patients with polycythemia vera and essential thrombocythemia. The American journal of medicine. 2004;117(10):755-61. The American journal of medicine. , 117, 755-61.

PASSAMONTI, F. \& RUMI, E. 2009. Clinical relevance of JAK2 (V617F) mutant allele burden. Haematologica, 94, 7-10.

PASSAMONTI, F., RUMI, E., PUNGOLINO, E., MALABARBA, L., BERTAZZONI, P., VALENTINI, M., ORLANDI, E., ARCAINI, L., BRUSAMOLINO, E., PASCUTTO, C., CAZZOLA, M., MORRA, E. \& LAZZARINO, M. 2004. Life expectancy and prognostic factors for survival in patients with polycythemia vera and essential thrombocythemia. Am J Med, 117, 755-61.

SCHERBER, R., DUECK, A. C., JOHANSSON, P., BARBUI, T., BAROSI, G., VANNUCCHI, A. M., PASSAMONTI, F., ANDREASSON, B., FERARRI, M. L., RAMBALDI, A., SAMUELSSON, J., BIRGEGARD, G., TEFFERI, A., HARRISON, C. N., RADIA, D. \& MESA, R. A. 2011. The Myeloproliferative Neoplasm Symptom Assessment Form (MPN$\mathrm{SAF})$ : international prospective validation and reliability trial in 402 patients. Blood, 118, 4018.

SPIVAK, J. L., BAROSI, G., TOGNONI, G., BARBUI, T., FINAZZI, G., MARCHIOLI, R. \& MARCHETTI, M. 2003. Chronic myeloproliferative disorders. Hematology Am Soc Hematol Educ Program, 200-24.

SROUR, S. A., DEVESA, S. S., MORTON, L. M., CHECK, D. P., CURTIS, R. E., LINET, M. S. \& DORES, G. M. 2016. Incidence and patient survival of myeloproliferative neoplasms and myelodysplastic/myeloproliferative neoplasms in the United States, 2001-12. Br J Haematol, 174, 382-96.

SROUR SA, D. S., MORTON LM, CHECK DP, CURTIS RE, LINET MS, ET AL. 2016. 
Incidence and patient survival of myeloproliferative neoplasms and myelodysplastic/myeloproliferative neoplasms in the United States, 2001-12. . British journal of haematology. 2016;174(3):382-96.

STEIN BL, R. A., SPIVAK JL, MOLITERNO AR. 2011. Gender and Vascular Complications in the JAK2 V617F-Positive Myeloproliferative Neoplasms. . Thrombosis., 2011.

STEIN, B. L., SARAF, S., SOBOL, U., HALPERN, A., SHAMMO, J., RONDELLI, D., MICHAELIS, L., ODENIKE, O., RADEMAKER, A., ZAKARIJA, A., MCMAHON, B., SPIVAK, J. L. \& MOLITERNO, A. R. 2013. Age-related differences in disease characteristics and clinical outcomes in polycythemia vera. Leukemia \& Lymphoma, 54, 1989-1995.

TEFFERI A, J. V. 2008. Classification and diagnosis of myeloproliferative neoplasms: the 2008 World Health Organization criteria and point-of-care diagnostic algorithms. . Leukemia 22, 14-22.

TEFFERI A, C. F., MESA R, PASSAMONTI F, VERSTOVSEK S, VANNUCCHI AM, ET AL. 2013. Revised response criteria for myelofibrosis: International Working GroupMyeloproliferative Neoplasms Research and Treatment (IWG-MRT) and European LeukemiaNet (ELN) consensus report. Blood. 2013;122(8):1395-8.

TEFFERI, A., LASHO, T. L., JIMMA, T., FINKE, C. M., GANGAT, N., VAIDYA, R., BEGNA, K. H., AL-KALI, A., KETTERLING, R. P., HANSON, C. A. \& PARDANANI, A. 2012. One Thousand Patients With Primary Myelofibrosis: The Mayo Clinic Experience. Mayo Clin Proc, 87, 25-33.

TEFFERI A, L. T., JIMMA T, FINKE CM, GANGAT N, VAIDYA R, ET AL. 2012. One Thousand Patients With Primary Myelofibrosis: The Mayo Clinic Experience. . Mayo Clinic proceedings. 2012;87(1):25-33.

TIBES, R. \& MESA, R. A. 2013. Emerging drugs for polycythemia vera. Expert Opin Emerg Drugs, 18, 393-404.

TIBES R, M. R. E. D. F. P. V. 2013. Expert opinion on emerging drugs. 2013;18(3):393-404. .

VARDIMAN JW, H. N., BRUNNING R. 2003. The World Health Organization (WHO) classification of the myeloid neoplasms. B. Blood. , 100, 2292-302

YESILOVA AM, Y. S., YAVUZER H, CENGIZ M, TOPRAK ID, HANEDAR E, ET AL. 2017. Analysis of thrombosis and bleeding complications in patients with polycythemia vera: a Turkish retrospective study. International Journal of Hematology. 2017;105(1):70-78 